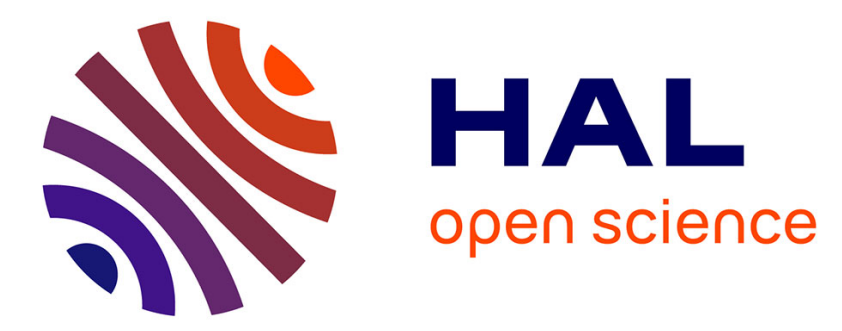

\title{
Atom transfer radical polymerization of methyl acrylate with molybdenum halides as catalysts in an ionic liquid
}

Sébastien Maria, Tadeusz Biedroń, Rinaldo Poli, Przemyslaw Kubisa

\section{To cite this version:}

Sébastien Maria, Tadeusz Biedroń, Rinaldo Poli, Przemyslaw Kubisa. Atom transfer radical polymerization of methyl acrylate with molybdenum halides as catalysts in an ionic liquid. Journal of Applied Polymer Science, 2007, 105 (1), pp.278-281. 10.1002/app.26046 . hal-03194553

\section{HAL Id: hal-03194553 \\ https://hal.science/hal-03194553}

Submitted on 9 Apr 2021

HAL is a multi-disciplinary open access archive for the deposit and dissemination of scientific research documents, whether they are published or not. The documents may come from teaching and research institutions in France or abroad, or from public or private research centers.
L'archive ouverte pluridisciplinaire HAL, est destinée au dépôt et à la diffusion de documents scientifiques de niveau recherche, publiés ou non, émanant des établissements d'enseignement et de recherche français ou étrangers, des laboratoires publics ou privés. 


\title{
Atom Transfer Radical Polymerization of Methyl Acrylate with Molybdenum Halides as Catalysts in an Ionic Liquid
}

\author{
Sebastien Maria ${ }^{1}$, Tadeusz Biedroń ${ }^{2}$, Rinaldo Poli ${ }^{1}$ and Przemysław Kubisa ${ }^{2}$ \\ 1. Laboratoire de Chimie de Coordination, UPR CNRS 8241 liée par convention à \\ l'Université Paul Sabatier et à l'Institut National Polytechnique de Toulouse, 205 Route de \\ Narbonne, 31077 Toulouse Cedex, France \\ 2, Centre of Molecular and Macromolecular Studies, Polish Academy of Sciences, 112 \\ Sienkiewiczam 90-363 Łódź, Poland
}

Summary: Atom Transfer Radical Polymerization (ATRP) of methyl acrylate in 1-butyl-3methyl-imidazolium hexafluorophosphate $\left(\left[\mathrm{bmim}^{2}\left[\mathrm{PF}_{6}\right]\right)\right.$ was studied with molybdenum halide catalytic systems. Combination of bromine containing initiator (ethyl-2-bromopropionate) with chloride containing catalyst $\left(\mathrm{MoCl}_{3}\left(\mathrm{PMe}_{3}\right)_{3} / \mathrm{MoCl}_{4}\left(\mathrm{PMe}_{3}\right)_{3}\right)$ leads to controlled polymerization and MALDI TOF analyses of the resulting polymers indicate that the reversibly deactivated macromolecules contain both bromine and chloride end-groups.

\section{Introduction}

Atom Transfer Radical Polymerization (ATRP) is the most versatile method of controlled radical polymerization. [1-5] ATRP is a catalytic process based on a reversible activation-deactivation cycle, involving a low oxidation state metal complex reacting with an alkyl halide to generate radicals and a corresponding higher oxidation state metal complex, as shown schematically below:

Insert Scheme 1 here

$$
\begin{array}{cc}
\begin{array}{c}
-\mathrm{M}-\mathrm{X}+\mathrm{Mt}-\mathrm{X}_{\mathrm{Z}} \\
\text { dormant species }
\end{array} & \longrightarrow-\mathrm{M}^{\bullet}+\mathrm{Mt}-\mathrm{X}_{\mathrm{Z}+1} \\
\mathrm{X}=\mathrm{Cl}, \mathrm{Br} & \mathrm{Mt}=\text { e.g. } \mathrm{Cu}, \mathrm{Ru}, \mathrm{Fe}, \mathrm{Mo},
\end{array}
$$


Most commonly the metal complexes are copper halides but many other transition metal complexes have been successfully used including e.g. ruthenium and iron complexes. Recently the application of molybdenum-based catalysts for ATRP of styrene has been reported. [6,7]

Not all of these complexes are well soluble in bulk monomers or in typical organic solvents. This stimulated the interest in using ionic liquids as solvents for ATRP processes. Ionic liquids are organic salts that are liquid at ambient temperatures, the typical example being 1-butyl-3-methylimidazolium hexafluorophosphate (abbreviated as $\left[\mathrm{bmim}^{-}\left[\mathrm{PF}_{6}\right]\right.$ ): [810]

\section{Insert Scheme 2 here}

$$
\mathrm{C}_{4} \mathrm{H}_{9}-\mathrm{N}_{\stackrel{\oplus}{\oplus}}^{i} \mathrm{~N}-\mathrm{CH}_{3}, \mathrm{PF}_{6} \Theta
$$

Ionic liquids are non-volatile solvents that readily dissolve many inorganic compounds, including those that are used as ATRP catalysts. Some monomers that can polymerize by ATRP (e.g. styrene) show, however, only limited solubility in typical ionic liquids. Other typical monomers, like methyl acrylate and methyl methacrylate (as well as their polymers) are miscible with $[\mathrm{bmim}]\left[\mathrm{PF}_{6}\right]$.

It has been shown that conducting the ATRP of methyl methacrylate or methyl acrylate in $[\mathrm{bmim}]\left[\mathrm{PF}_{6}\right]$ offers the advantage of good catalyst solubility (therefore the reaction mixture is homogeneous and the residual catalyst can be easily separated from the polymer after polymerization) and may, in some instances, favorably affect the kinetics. Thus in the radical polymerization of methyl methacrylate it has been shown that the propagation rate constant is higher and the termination rate constant is lower than in bulk polymerization [11], which creates more favorable conditions for controlled polymerization. [12,13] The ATRP of acrylate esters is shown schematically below: 


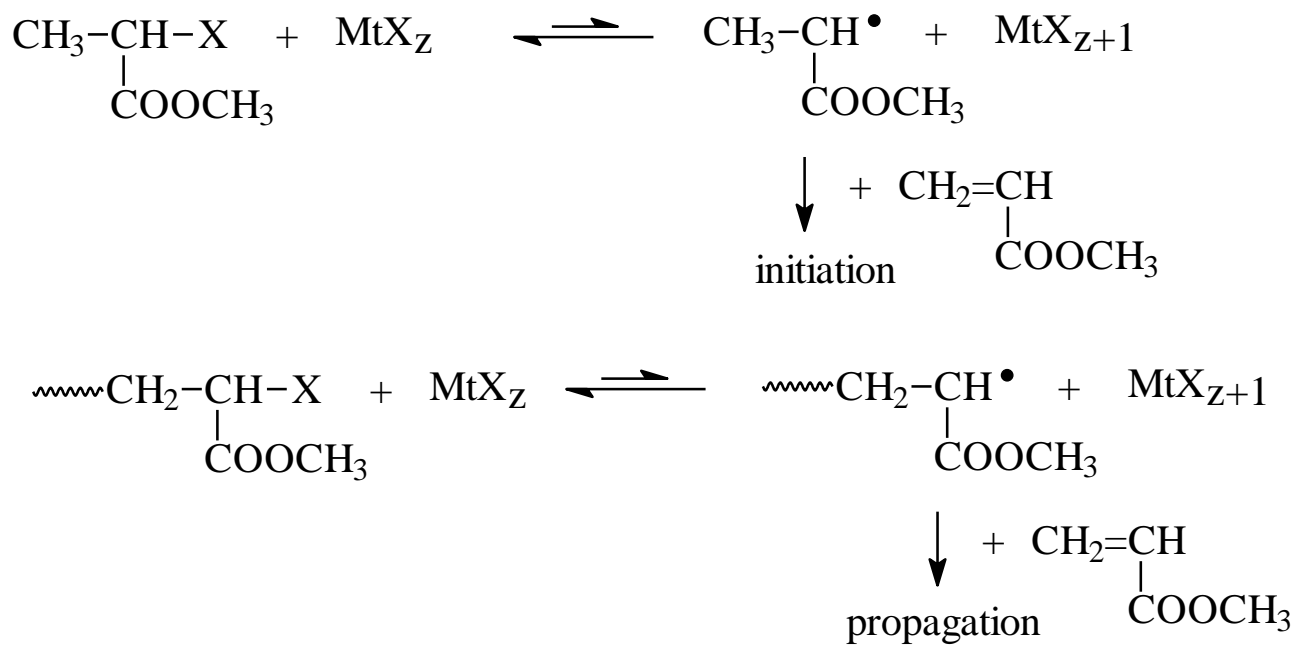

The studies of ATRP of (meth)acrylates in ionic liquids have been so far limited to the most commonly used catalytic system, namely $\mathrm{CuBr} / \mathrm{CuBr} 2 /$ amine ligand. In this communication we report on the attempts to perform methyl acrylate ATRP in $[\mathrm{bmim}]\left[\mathrm{PF}_{6}\right]$, using molybdenum based catalysts that have been successfully used by two of the present authors for styrene ATRP in toluene solvent [7]. Preliminary results on the application of this catalytic system for acrylates ATRP have been presented at the ACS meeting. [14]

The structure of the catalysts used in this work is shown in Scheme 3.

Insert Scheme 4 here

$\mathrm{MoCl}_{3}\left(\mathrm{PMe}_{3}\right) 3, \mathrm{MoCl}_{4}\left(\mathrm{PMe}_{3}\right) 3, \mathrm{MoBr}_{3}\left(\mathrm{PMe}_{3}\right) 3, \mathrm{MoBr}_{4}\left(\mathrm{PMe}_{3}\right)$

\section{Experimental}

Chemicals. Ethyl 2-bromopropionate was purchased from Aldrich and used as received. Methyl acrylate (from Aldrich) was purified by distillation under argon. 1- $n$-Butyl-3methylimidazolium hexafluorophosphate was obtained according to a procedure described in the literature [15] starting from 1-methylimidazol, butyl chloride and aqueous (60\%) hexafluorophosphoric acid. $\operatorname{MoCl}_{3}\left(\mathrm{PMe}_{3}\right)_{3}, \quad \operatorname{MoBr}_{3}\left(\mathrm{PMe}_{3}\right)_{3}, \quad \mathrm{MoBr}_{4}\left(\mathrm{PMe}_{3}\right)_{3} \quad$ and $\mathrm{MoCl}_{4}\left(\mathrm{PMe}_{3}\right)_{3}$ were obtained as described earlier. [16] 
Polymerizations. All polymerizations were carried out under dry and oxygen- free conditions (under vacuum or under argon). The monomer and the molybdenum complex(es) were dissolved in $[\mathrm{bmim}]\left[\mathrm{PF}_{6}\right]$ (the volume ratio of monomer to $[\mathrm{bmim}]\left[\mathrm{PF}_{6}\right]$ was $2 / 1$ ). Ethyl 2bromopropionate was then introduced to the stirred reaction under an argon atmosphere. The flask (under vacuum or under argon) was then immersed in an oil bath heated at the desired temperature. Samples of the polymerization mixture were withdrawn at different time intervals. A portion of the sample was dissolved in deuterated chloroform and the monomer conversion was determined by means of ${ }^{1} \mathrm{H}$ NMR spectroscopy. The remaining portion was extracted with chloroform (the chloroform extraction gave practically colorless polymer solutions) which, after the evaporation of the solvent, were used for the gel permeation chromatography (GPC) measurements.

Characterization. ${ }^{1} \mathrm{H}$ NMR spectra were recorded on a Bruker $300 \mathrm{MSL} 300 \mathrm{MHz}$ spectrometer. MALDI TOF spectra were performed on a Voyager Elite MALDI TOF spectrometer using dihydroxybenzoic acid as a matrix and nitrogen laser desorption at 337 nm. Sodium iodide was used as cationating agent. GPC measurements were performed using an LKB 2150 HPLC pump and a set of TSK-GEL G2000 HXL and G40000 HXL columns with $\mathrm{CH}_{2} \mathrm{Cl}_{2}$ as eluent. Double RI and MALS (multi-angle light scattering) detectors were used allowing the determination of the absolute values of the average molecular weights.

\section{Results and Discussion}

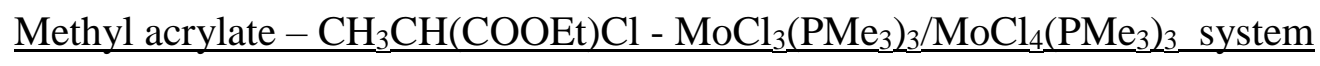

The methyl acrylate ATRP was conducted with $\mathrm{CH}_{3} \mathrm{CH}(\mathrm{COOEt}) \mathrm{Cl}$ as initiator and $\mathrm{MoCl}_{3}\left(\mathrm{PMe}_{3}\right)_{3} / \mathrm{MoCl}_{4}\left(\mathrm{PMe}_{3}\right)_{3}$ as a catalytic system at a $[\text { monomer }]_{0} /[\text { initiator }]_{0} /\left[\mathrm{Mo}^{\mathrm{III}}\right]_{0} /$ $\left[\mathrm{Mo}^{\mathrm{IV}}\right]_{0}$ ratio equal to $470 / 11 / 1 / 1.1$. At $60^{\circ} \mathrm{C}$ the polymerization proceeded fast $(57 \%$ conversion after $10 \mathrm{~min})$ and the polymer molecular weight $\left(\mathrm{Mn} \sim 10^{5}\right)$ was well above the calculated value. In the subsequent experiment the $\mathrm{MoCl}_{3}\left(\mathrm{PMe}_{3}\right)_{3}$ concentration was reduced 
5 times while the $\mathrm{MoCl}_{4}\left(\mathrm{PMe}_{3}\right)_{3}$ concentration was increased (the [monomer $]_{0} /[\text { initiator }]_{0} /$ $\left[\mathrm{Mo}^{\mathrm{III}}\right]_{0} /\left[\mathrm{Mo}^{\mathrm{IV}}\right]_{0}$ ratio was equal to $\left.470 / 11 / 0.2 / 1.8\right)$ Increasing the concentration of $\mathrm{MoCl}_{4}\left(\mathrm{PMe}_{3}\right)_{3}$, in order to shift the equilibrium shown in Scheme 1 to the left-hand side and to reduce the instantaneous concentration of growing radicals, improved the outcome only slightly. The rate of polymerization indeed decreased (35\% conversion after $3 \mathrm{~h}, 82 \%$ after $19 \mathrm{~h})$ but the molecular weight was still considerably higher $\left(\mathrm{M}_{\mathrm{n}} \sim 6 \times 10^{4}\right)$ than calculated for a controlled polymerization. It seems therefore that under typical ATRP conditions no control can be achieved with this catalytic system in the methyl acrylate polymerization.

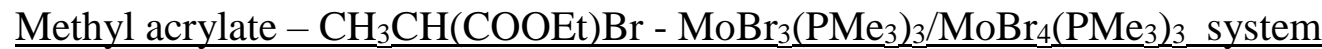

Replacing chlorine by bromine both in the initiator and in the catalyst led to a significant improvement. Thus, in the polymerization conducted at a $[\text { monomer }]_{0} /[\text { initiator }]_{0} /\left[\mathrm{Mo}^{\mathrm{III}}\right]_{0} /$ $\left[\mathrm{Mo}^{\mathrm{IV}}\right]_{0}$ ratio equal to $500 / 10 / 1 / 1.7$ at $60^{\circ} \mathrm{C}$, almost complete conversion was reached in $24 \mathrm{~h}$. The number average molecular weight was only slightly higher then the calculated value $\left(\mathrm{M}_{\mathrm{n}}\right.$ calcd $\left.=4480, \mathrm{M}_{\mathrm{n}}(\mathrm{GPC})=5730\right)$ but the dispersity was still relatively high. In order to improve the control the $\mathrm{MoBr}_{4}\left(\mathrm{PMe}_{3}\right)_{3}$ concentration was increased in subsequent experiments. This, however, led to an unexpected result. The polymerization proceeded in the ionic liquid phase, as evidenced by an increasing solution viscosity, but at the same time significant quantities of a white solid formed on the ampoule walls. The recovered solid was insoluble in common organic solvents. Solid state NMR $\left({ }^{13} \mathrm{C}\right.$ CP MAS) showed four signals characteristic of carbon atoms in methyl acrylate unit. In Fig. 1, the ${ }^{13} \mathrm{C}$ CP MAS spectrum of the solid product is compared with the typical spectrum of poly(methyl acrylate) (obtained by conventional ATRP in bulk) recorded in $\mathrm{CDCl}_{3}$ solution. 
The elemental analysis results were also essentially consistent with assumption that the insoluble solid is indeed poly(methyl acrylate) ( $\mathrm{C}$ - found $56.00 \%$, calcd $55.80 \%, \mathrm{H}$ - found $7.20 \%$, calcd $8.13 \%$ ). The polymer isolated from solution had a considerably higher molecular weight than that obtained at lower $\mathrm{MoBr}_{4}\left(\mathrm{PMe}_{3}\right)_{3}$ concentration (the polymer isolated at $30 \%$ conversion had $M_{n}=28400$ as compared to the calculated $M_{n}=1500$ ). The MALDI TOF analysis of the polymer isolated from the solution showed the presence of two populations of macromolecules. In Table 1 the $\mathrm{m} / \mathrm{z}$ values of the signals appearing in the spectrum are shown and the assignments are given.

\section{Insert Table 1 here}

In a control experiment, the catalyst $\left(\mathrm{MoBr}_{3}\left(\mathrm{PMe}_{3}\right)_{3} / \mathrm{MoBr}_{4}\left(\mathrm{PMe}_{3}\right)_{3}\right)$ was added to the methyl acrylate solution in ionic liquid in the absence of initiator. Significant quantities of insoluble polymer were formed in this system, in addition to small amounts of soluble, very high molecular weight polymer. This confirms that an unknown side-reaction occurs between $\mathrm{MoBr}_{4}\left(\mathrm{PMe}_{3}\right)_{3}$ and $[\mathrm{bmim}]\left[\mathrm{PF}_{6}\right]$ (no formation of insoluble polymer was observed when $\mathrm{MoBr}_{3}\left(\mathrm{PMe}_{3}\right)_{3}$ was used in the absence of $\mathrm{MoBr}_{4}\left(\mathrm{PMe}_{3}\right)_{3}$, but the polymerization in this system was not controlled) and the products of this reaction are able to initiate the methyl acrylate polymerization leading to the formation of branched high-molecular weight polymer in solution and eventually to cross-linked polymer. The formation of insoluble polymer on the reaction vessel walls implies that some volatile products are involved. At present we do not have enough data to speculate on the exact nature of this side-reaction.

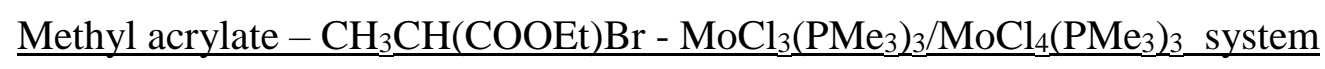

It has been shown earlier by two of the present authors that $\mathrm{MoCl}_{3}\left(\mathrm{PMe}_{3}\right)_{3}$ is a more active catalyst than $\mathrm{MoBr}_{3}\left(\mathrm{PMe}_{3}\right)_{3}$ for the styrene ATRP in toluene (corresponding apparent polymerization rate constants at $90^{0} \mathrm{C}$ are equal to $1.42 \times 10^{-4} \min ^{-1}$ and $5.49 \times 10^{-5} \mathrm{~min}^{-1}$ 
respectively). [7] Both catalysts, however, are capable of catalyzing the styrene controlled polymerization, although the higher rate observed for $\mathrm{MoCl}_{3}\left(\mathrm{PMe}_{3}\right)_{3}$ implies a higher growing radical concentration. In the case of methyl acrylate polymerization in $[\mathrm{bmim}]\left[\mathrm{PF}_{6}\right]$, $\mathrm{MoCl}_{3}\left(\mathrm{PMe}_{3}\right)_{3}$ gives fast polymerization to high-molecular weight polymer even in the presence of an excess of $\mathrm{MoCl}_{4}\left(\mathrm{PMe}_{3}\right)_{3}$. Apparently the deactivation reaction in this system is not effective and the polymerization proceeds as a conventional radical polymerization.

The $\mathrm{MoBr}_{3}\left(\mathrm{PMe}_{3}\right)_{3} / \mathrm{MoBr}_{4}\left(\mathrm{PMe}_{3}\right)_{3}$ system seems to be much more effective for control of the methyl acrylate polymerization in $\left[\mathrm{bmim}^{-}\right]\left[\mathrm{PF}_{6}\right]$, but the side-reaction involving $\mathrm{MoBr}_{4}\left(\mathrm{PMe}_{3}\right)_{3}$ leads to deviation from the controlled polymerization scheme.

Thus, in the subsequent series of experiments the mixed system was applied involving bromine containing the $\mathrm{CH}_{3} \mathrm{CH}(\mathrm{COOEt}) \mathrm{Br}$ initiator and the chloride containing catalyst $\left(\mathrm{MoCl}_{3}\left(\mathrm{PMe}_{3}\right)_{3} / \mathrm{MoCl}_{4}\left(\mathrm{PMe}_{3}\right)_{3}\right)$. The polymerization conducted at a [monomer $]_{0} /$ [initiator $]_{0} /$ $\left[\mathrm{Mo}^{\mathrm{III}}\right]_{0} /\left[\mathrm{Mo}^{\mathrm{IV}}\right]_{0}$ ratio equal to $500 / 10 / 1 / 2$ at $60^{\circ} \mathrm{C}$ was terminated at $80 \%$ conversion. There was a good agreement between the experimental and the theoretical molecular weights $\left(\mathrm{M}_{\mathrm{n}}(\mathrm{GPC})=3500, \mathrm{M}_{\mathrm{n}}\right.$ calcd $\left.=3640\right)$ and the dispersity was relatively narrow $\left(\mathrm{M}_{\mathrm{w}} / \mathrm{M}_{\mathrm{n}}=\right.$ 1.38). The polymer MALDI TOF analysis indicates the presence of two main populations of the macromolecules, one containing $\mathrm{CH}_{3} \mathrm{CH}(\mathrm{COOEt})$ - moiety as the head-group and $-\mathrm{Br}$ as the end-group and the other one containing the same head-group and a $-\mathrm{Cl}$ end-group. In addition, a third minor series is observed. Macromolecules of this series contain the same head-group and saturated $-\mathrm{CH}_{2}-\mathrm{CH}_{2}\left(\mathrm{COOCH}_{3}\right)$ end-groups, formed by irreversible termination. It is interesting to note that the signals corresponding to macromolecules terminated with bromine and chlorine have similar intensities. At $\left[\mathrm{CH}_{3} \mathrm{CH}(\mathrm{COOEt}) \mathrm{Br}\right]_{0} /$ $\left[\mathrm{MoCl}_{3}\right]_{0} /\left[\mathrm{MoCl}_{4}\right]_{0}$ ratio equal to $10 / 1 / 2$ the proportion of bromine and chlorine introduced with the initiator and catalyst is $10 / 11$. 
This observation was a little unexpected because catalytic systems containing chloride and bromide behave differently, which could indicate that the positions of activationdeactivation equilibria are different in both cases. In the system in which chloride and bromide are present in nearly equal proportion, however, the molybdenum compounds form mixed halides $\left(\mathrm{MoCl}_{n} \mathrm{Br}_{3-\mathrm{n}}\right.$ and $\left.\mathrm{MoCl}_{n} \mathrm{Br}_{4-\mathrm{n}}\right)$ and the efficiency of such mixed halides in controlling the activation-deactivation equilibria may not be related in a simple way to the efficiency of catalysts containing either only chloride or only bromine.

\section{$\underline{\text { Conclusions }}$}

It has been shown earlier that the methyl acrylate ATRP can be advantageously conducted in [bmim] $\left[\mathrm{PF}_{6}\right]$ with $\mathrm{CuBr} / \mathrm{CuBr}_{2} /$ pentametyldiethylenetriamine (PMDETA) system. The situation is more complex with molybdenum based catalytic systems that proved to be effective in the styrene ATRP. $\mathrm{MoCl}_{3}\left(\mathrm{PMe}_{3}\right)_{3} / \mathrm{MoCl}_{4}\left(\mathrm{PMe}_{3}\right)_{3}$ is not effective in conjunction with chloride-containing initiator while for the $\mathrm{MoBr}_{3}\left(\mathrm{PMe}_{3}\right)_{3} / \mathrm{MoBr}_{4}\left(\mathrm{PMe}_{3}\right)_{3}$ catalyst in conjunction with bromine containing initiator, side-reaction (reaction of $\mathrm{MoBr}_{4}\left(\mathrm{PMe}_{3}\right)_{3}$ with the cationic fragment of the ionic liquid) obscures the results. The combination of the bromine containing initiator with the chloride catalyst leads to a controlled polymerization and the polymer MALDI TOF analysis indicates that reversibly deactivated macromolecules contain both bromine and chlorine end-groups.

\section{Literature}

1.Wang, J-. S.; Matyjaszewski, K. J. Am Chem Soc 1995, 117, 5614.

2.Kato, M.; Kamigaito, M.; Sawamoto, M.; Higashimura, T. Macromolecules 1995, 28, 1721.

3. Patten, T. E.; Matyjaszewski, K. Acc Chem Res 1999, 12, 895.

4. "Controlled Radical Polymerization”, Matyjaszewski, K., Ed.; ACS Symposium Series 685, ACS Washington DC, 1997. 
5. “Controlled/Living Radical Polymerization, Matyjaszewski, K.; Ed.; ACS Symposium Series 768, ACS, Washington DC, 2000.

6. Stoffelbach, F.; Claverie, F.; Poli, R. C. R. Acad. Sci. Paris C 2002, 39, 2099.

7. Maria, S.; Stoffenbach, F.; Mata, J.; Daran, J.-C.; Richard, P.; Poli, R. J Am Chem Soc $2005,127,5946$.

8. Welton, T.; Wasserscheid, P. eds. Ionic Liquids in Synthesis. Weinheim:Wiley-VCH, 2002.

9. Rogers, R.; Seddon K. eds. Ionic Liquids: Industrial Applications to Green Chemistry. ACS Symposium Series 818. Washington DC: American Chemical Society, 2002.

10. Welton, T. Room-temperature ionic liquids. Solvents for Synthesis and Catalysis. Chem. Rev. 1999, 99, 2071.

11. Harrison, S.; MacKenzie, S. R.; Haddleton, D. M. Chem. Commun. 2002, 2850.

12. Biedroń, T; Kubisa P. Macromol. Rapid Commun. 2001, 22, 1237.

13. Biedroń, T.; Kubisa, P. J. Polym. Sci., Pol. Chem. Ed. 2002, 40, 2799.

14. Maria, S.; Biedroń, T.; Poli, R.; Kubisa, P. ACS Polymer Prepr. 2005, 46(2), 158.

15. Huddleston, J. G.; Willauer, H. D.; Swatloski, R. P.; Visser, A. E.; Rogers, R. D. J. Chem. Soc. Chem. Commun. 1998, 1765. 
Table 1

$\mathrm{M} / \mathrm{z}$ values of the signals appearing in MALDI TOF spectrum of poly(methyl acrylate) obtained with the $\mathrm{CH}_{3} \mathrm{CH}(\mathrm{COOEt}) \mathrm{Br}-\mathrm{MoBr}_{3}\left(\mathrm{PMe}_{3}\right)_{3} / \mathrm{MoBr}_{4}\left(\mathrm{PMe}_{3}\right)_{3}$ system.

\begin{tabular}{|l|l|l|l|l|l|}
\hline $\mathrm{m} / \mathrm{z}_{\text {obs. }}{ }^{\mathrm{a}}$ & $\mathrm{m} / \mathrm{z}$ cald & Formula $^{\mathrm{b}}$ & $\mathrm{m} / \mathrm{z}$ obs. $^{\mathrm{a}}$ & $\mathrm{m} / \mathrm{z}^{\text {cald }}$ & Formula $^{\mathrm{b}}$ \\
\hline 4767 & 4767 & In-[MA] ${ }_{53}-\mathrm{Br}$ & 4804 & 4804 & bmim-[MA] $]_{53}-\mathrm{Br}$ \\
\hline 4852 & 4853 & In-[MA] $]_{54}-\mathrm{Br}$ & 4891 & 4890 & bmim-[MA] $]_{54}-\mathrm{Br}$ \\
\hline 5025 & 5025 & In-[MA] $]_{56}-\mathrm{Br}$ & 5063 & 5062 & bmim-[MA] $]_{56}-\mathrm{Br}$ \\
\hline 5111 & 5111 & In-[MA] $]_{57}-\mathrm{Br}$ & 5149 & 5148 & bmim-[MA] $]_{57}-\mathrm{Br}$ \\
\hline 5197 & 5197 & In-[MA] $]_{58}-\mathrm{Br}$ & 5235 & 5236 & bmim-[MA] $]_{58}-\mathrm{Br}$ \\
\hline
\end{tabular}

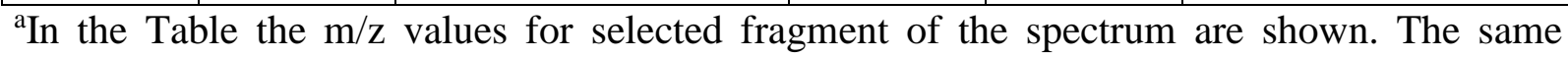
pattern is observed for the whole spectrum. ${ }^{\mathrm{b}} \mathrm{In}$ - denotes head-group derived from initiator: In $=\mathrm{CH}_{3} \mathrm{CH}\left(\mathrm{COOC}_{2} \mathrm{H}_{5}\right)$-, bmim- denotes the head-group derived from the 1-butyl-3methylimidazolium moiety, MA denotes the methyl acrylate unit. 
Fig. 1

A. ${ }^{13} \mathrm{C}$ NMR solution (in $\mathrm{CDCl}_{3}$ ) spectrum of poly(methyl acrylate) obtained by a conventional ATRP process.

B. ${ }^{13} \mathrm{C}$ CP MAS spectrum of solid insoluble product obtained in polymerization of methyl acrylate catalyzed by the $\mathrm{MoBr}_{3}\left(\mathrm{PMe}_{3}\right)_{3} / \mathrm{MoBr}_{4}\left(\mathrm{PMe}_{3}\right)_{3}$ system.

A

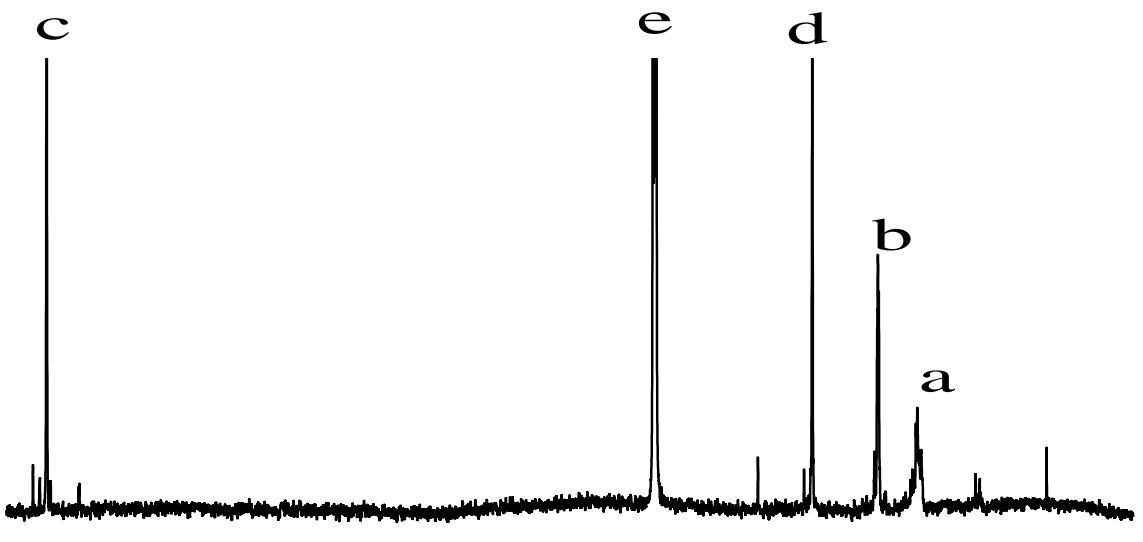

B

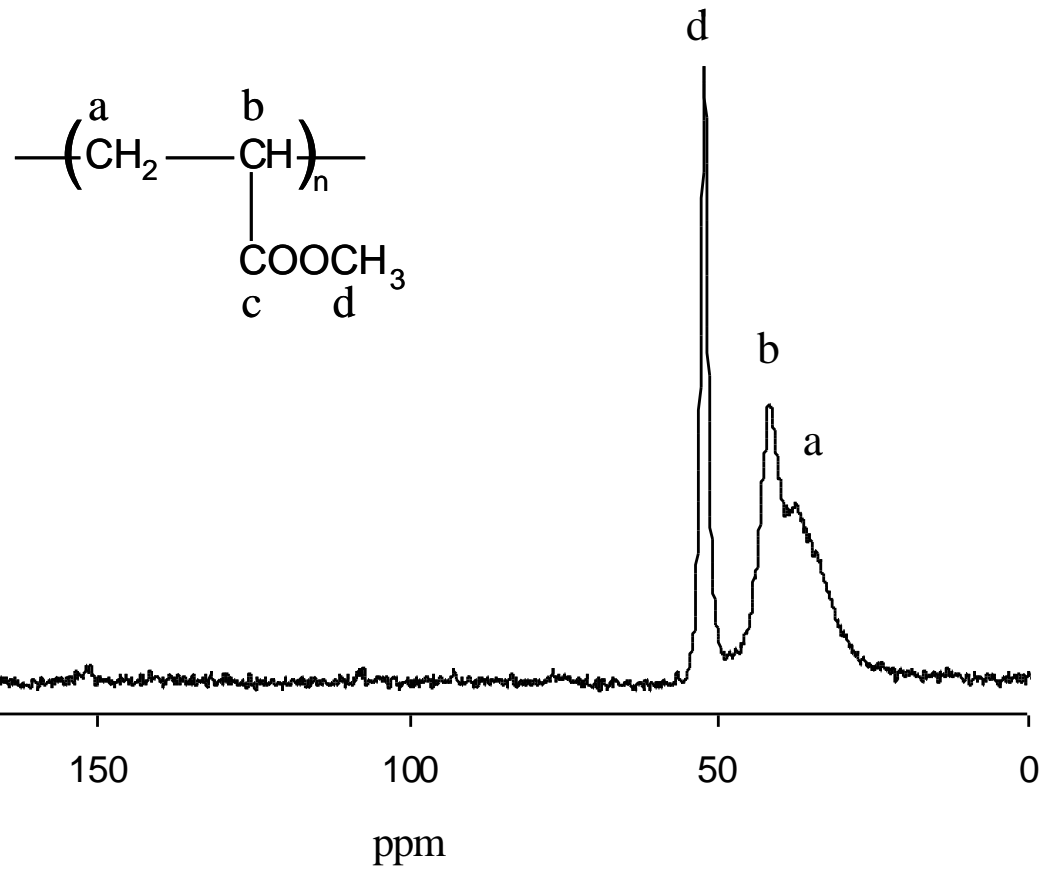

